\title{
O PRZEDSIĘBIORCZOŚCI JAKO KLUCZOWEJ KOMPETENCJI PRZYSZŁOŚCI
}

DOI: $10.33141 /$ po.2019.09.05

\author{
Julita Majczyk
}

\section{Wprowadzenie}

W teorii ekonomii można odwołać się do paradygmatu gospodarki przedsiębiorczej, gdzie przedsiębiorczość stanowi główny czynnik rozwoju gospodarczego, a istotnymi uczestnikami rynku są małe i średnie przedsiębiorstwa (Wach, 2014), które stanowią narzędzie ograniczania bezrobocia, eliminują nierówności społeczne i ekonomiczne oraz zwiększają poziom dobrobytu społeczności regionalnych. Małe i średnie podmioty w 2015 roku miały ponad 50\% udziału w tworzeniu $\mathrm{PKB}$, w tym mikroprzedsiębiorstwa tworzyły ponad 30\% wartości dodanej brutto (PARP, 2018, s. 17). Celem niniejszego artykułu jest wskazanie kompetencji przedsiębiorczych kluczowych w przyszłości, których kształtowanie uwarunkowane jest przykładowo rozwojem mediów społecznościowych, przyśpieszeniem informatyzacji, usieciowienia powiązań społecznych czy ekonomicznych.

\section{Kompetencje kluczowe w rozwoju gospodarczym}

W ykorzystaniu szansy rynkowej sprzyja twórcza kombinacja czynników produkcji. Przy czym pośród czynników wytwórczych to technologia i przedsiębiorczość (Richert-Kaźmierska, 2010, s. 272) czy wiedza i technologia informacyjno-komunikacyjna (TIK) (Sobczyk, 2016, s. 173) stanowią kolejny filar rozwoju gospodarczego. Rynek pracy zmienia się pod wpływem zjawisk zachodzących poza jego kontrolą, co w dalszej kolejności wymusza zmiany w pożądanych kompetencjach pracowników, które tę adaptację do zmian zapewnią.
Posługiwanie się odmiennymi pojęciami utrudnia rozważania nad istotnością kompetencji. Trudniej jest wówczas kształcić potencjalnych pracowników w kierunku potrzeb zgłaszanych przez środowisko biznesowe (Goliński i in., 2017, s. 57). Dążąc do unifikacji terminologii, przyjęto Zalecenie Rady Unii Europejskiej (2018) na temat ośmiu kompetencji kluczowych determinujących samorealizację, szanse na zatrudnienie, włączenie społeczne czy zdrowie. Należą do nich: rozumienie i tworzenie informacji; wielojęzyczność; przedsiębiorczość; świadomość i ekspresja kulturalna; kompetencje matematyczne oraz kompetencje w zakresie nauk przyrodniczych, technologii i inżynierii; kompetencje cyfrowe; obywatelskie; osobiste, społeczne i umiejętność uczenia się. Należy podkreślić, że kompetencje kluczowe nie podlegają gradacji. $\mathrm{Z}$ kolei do kompetencji niezbędnych w przyszłości należą te uwarunkowane indywidualnymi zdolnościami do nauki, adaptacji i rozwoju osobistego. Ich rosnące znaczenie podyktowane jest kierunkiem zmian cywilizacyjnych, przykładowo rozwojem technologii (Kwiatkowski, 2018, s. 23). Do determinantów zmian należą także: postępująca automatyzacja i serwicyzacja gospodarek, dyfuzja postępu technicznego, internacjonalizacja organizacji, globalizacja i zmiany demograficzne (Szukalski, 2017, s. 260). $\mathrm{Z}$ kolei rozwój technologii informacyjnych i postępująca globalizacja doprowadziły do delokalizacji miejsc pracy, wysokiego tempa pracy i ciągłej redefinicji konkurencji, co wymusiło nowe modele współpracy i e-przywództwo, tj. przewodzenie zespołom, w których rozproszenie geograficzne pracowników utrudnia osobisty kontakt (Majczyk, 2019, s. 23) za pośrednictwem nowych technologii 
(jak komunikacja elektroniczna w przestrzeni wirtualnej). Nabywanie i rozwój nowych kompetencji uwarunkowane jest również rodzajem wykonywanej pracy, przynależnością do wybranej grupy społecznej, ale i rozwojem mediów społecznościowych, przyśpieszeniem informatyzacji czy usieciowieniem społecznym bądź ekonomicznym. Stąd do pożądanych kompetencji w przyszłości mają należeć: umiejętność nadawania sensu (sense making), inteligencja społeczna, adaptacyjne, obliczeniowe, jak i projektowe myślenie, umiejętność funkcjonowania $\mathrm{w}$ różnych środowiskach kulturowych, znajomość nowych mediów, umiejętność filtracji danych, podejście interdyscyplinarne do problemu i umiejętność współpracy wirtualnej (Borowiec-Gabryś i in., 2018, s. 72-73). Niestety, badania przeprowadzone przez T. Kupczyk i M. Stor (2017, 145-146) wskazują, że przedsiębiorstwa $\mathrm{z}$ Polski rzadziej niż te z Austrii i Hiszpanii dokonują oceny stopnia dopasowania kompetencji do celów lub strategii przedsiębiorstwa. Najrzadziej też oceniają znaczenie kompetencji w przyszłości. Takie podejście utrudnia zaprojektowanie skutecznego procesu zdobywania kompetencji na dobrym poziomie, co może negatywnie wpływać na wyniki i rozwój przedsiębiorstw, szczególnie w dobie wysokiej zmienności otoczenia.

Zdaniem B.A. Glinkowskiej (2017, s. 65-66), do kompetencji, które zyskały na znaczeniu w 2017 roku, należą: charyzma, uprzejmość, zrozumienie, motywacja, umiejętność słuchania, umiejętność przewidywania, odporność na stres, wytrwałość w dążeniu do celu, równowaga emocjonalna, wyobraźnia i kreatywność, podejmowanie ryzyka, ale i doświadczenie zawodowe zdobywane zagranicą. Autorka wskazuje, że menedżer w przyszłości będzie pełnił częściej rolę lidera, stąd wśród kompetencji, które powinien posiadać, wymienia także umiejętność komunikowania się, w tym artykułowania celów, umiejętność konceptualnego myślenia i działania, umiejętność wnioskowania czy budowania i rozwijania współpracy w zespołach wielokulturowych. Tymczasem od absolwentów w najwyższym stopniu oczekuje się znajomości języków obcych i umiejętności korzystania z zasobów Internetu, prowadzenia dyskusji i prezentacji argumentów w sposób zrozumiały dla audytorium, pracę pod presją czasu i pracę $\mathrm{w}$ zespole, zdolność szukania kreatywnych rozwiązań problemów i wytrwałość $\mathrm{w}$ dążeniu do realizacji zadań w dłuższym okresie czasu (Dorożyński i in., 2016, s. 98-99). A. Stachowicz-Stanusch i A. Aleksander (2018) na podstawie przeglądu badań w zakresie kompetencji pracowniczych wskazały, że w przyszłości ważne będę umiejętności analityczne, w tym zbierania, filtrowania, przetwarzania danych i wnioskowania. Ponadto umiejętności cyfrowe oraz obsługa czy programowanie urządzeń, które mogłyby zastąpić ludzi, biorąc pod uwagę choćby rozwój inteligentnych systemów i maszyn, rozwój nowych środków komunikacji i technologii społecznościowych. W przypadku inżynierów „wyróżnikiem kompetencji przyszłości jest powiązanie umiejętności technicznych (których nabycie wymaga solidnej edukacji), przymiotów charakterologicznych (trudniejszych do wyćwiczenia) i umiejętności miękkich” (Instytut Analiz Rynku Pracy,
2019, s. 17) - kompetencją ważną jest natomiast kreatywność determinująca wdrażanie innowacji technologicznych i nawiązywanie relacji między pracownikami.

W badaniu przeprowadzonym przez A. Rakowską i A. Sitko-Lutek (2016) pośród kompetencji ważnych w 2021 roku wymieniono: umiejętność pracy w zespołach wirtualnych - w tym umiejętność zaangażowania i motywowania pracowników w rozproszonych lokalizacjach; kreatywność; adaptację; biegłość w nowych mediach i krytyczną ocenę ich wykorzystania; elastyczność; inteligencję społeczną; umiejętność uczenia się oraz transkulturowość. W raporcie Eurofound (2018, s. 8) wskazano, że na znaczeniu w okresie od 2015 do 2030 roku zyskają zadania intelektualne, które wymagają przekształcania informacji i aktywnego rozwiązywania problemów związanych z przetwarzaniem informacji, oraz zadania społeczne, obejmujące nawiązywanie relacji społecznych. Stąd wśród kompetencji przyszłości wymienia się te odnoszące się do umiejętności przetwarzania i tworzenia informacji biznesowych, umiejętności liczenia (analityczne), kreatywności, zbierania i ewaluacji informacji. W przypadku zadań społecznych kompetencje obejmują umiejętność perswazji i sprzedaży, zarządzanie/koordynację, nauczanie i służenie innym - co nawiązuje do zadań skoncentrowanych na otaczaniu innych opieką. Do metod determinowanych przez wybraną technologię i formę organizacji pracy mają należeć wyższa niezależność pracownika w realizacji zadań i umiejętność pracy zespołowej. Wśród narzędzi podkreśla się z kolei te związane $\mathrm{z}$ wykorzystaniem TIK. Odpowiednio TIK, przetwarzanie i tworzenie informacji biznesowych, umiejętność perswazji i sprzedaży oraz służenia innym postrzega się jako kompetencje kluczowe.

\section{Przedsiębiorczość i kompetencje przedsiębiorcze}

$\mathbf{Z}$ daniem E. Hauswalda (1919, s. 22), jednego z klasyków polskiej myśli organizatorskiej, przedsiębiorczość zdefiniowana ,jako inicyatywa i pierwotna energia twórcza w życiu gospodarczem" stanowiła fundament rozwoju gospodarczego. Energia twórcza, zdaniem Z. Baumana (1996), przedstawia przedsiębiorcę, który dokonuje twórczej destrukcji w drodze decyzji uwarunkowanych normami społecznie akceptowalnymi, wartością estetyczną lub mechanizmem poznawczym, tj. tym co można uznać za uzasadnione gospodarczo.

W przyjętej przez Radę UE deskrypcji kompetencji kluczowej w zakresie przedsiębiorczości - pojęcia tożsamego z przedsiębiorczością postrzeganą jako kompetencja czy kompetencji przedsiębiorczych (Rachwał, 2019) - uznanej za kompetencję przyszłości (Kwiatkowski, 2018), znajdują się z kolei „nowe odniesienia do proaktywności (współcześnie niezmiernie ważnej), zdolności do empatii, troski o innych ludzi i świat, a także przyjmowania odpowiedzialności i postaw etycznych" (Rachwał, 2019, s. 26). Podkreśla się przy tym decyzyjność, umiejętność komunikowania się, negocjowania, podejmowania ryzyka i radzenia sobie z niepewnością. Wcześniej B. Glinka i S. Gudkova (2011) w ramach kompetencji przedsię- 
biorczych uwzględniły: cechy osobowe, mechanizmy poznawcze, motywy, wiedzę i poczucie własnej skuteczności, które, jeśli jest wewnętrznie usytuowane, polega na wierze we własne kompetencje, skutecznym sprawstwie i ocenie radzenia sobie z przeszkodami (Bandura, 1997).

$\mathrm{W}$ odniesieniu do przedsiębiorców działających w sektorze MŚP kompetencje przedsiębiorcze pozytywnie wpływają na innowacyjność produktową, procesową i behawioralną (Ng, Kee, 2018). Pozytywny wpływ kompetencji strategicznych i etycznych przedsiębiorców na sukces biznesowy jest wzmacniany przez świadomy rozwój kompetencji sieciowych, które ułatwiają pozyskanie zasobów w postaci wiedzy, technologii i doświadczenia (Tehseen i in., 2019). By natomiast zapewnić prawidłowy rozwój startupu, zdaniem M. Wrobela (2018, s. 55-60), założyciel powinien posiadać takie kompetencje, jak: wiarygodność, gotowość do uczenia się, umiejętności komunikacyjne (wyrażania myśli i poglądów, strukturyzowania rozmów, słuchania), orientacja na klienta, na wyniki, odporność na funkcjonowanie $\mathrm{w}$ warunkach niepewności, możliwości analityczne i uznaną za kluczową umiejętność - wytrwałość. Wzrost potencjału przedsiębiorczego, kreatywność, myślenie przedsiębiorcze ukierunkowane na osiąganie celów i efektywność na pierwszym etapie działań ma z kolei ułatwiać znajomość języka angielskiego i narzędzi nowych technologii, jak na przykład Team Viewer czy Voxopop (Murtazova, Murtazova, 2018). Postrzeganie problematyki kompetencji przedsiębiorczych kluczowych w przyszłości pośród polskich przedsiębiorców zaprezentowano w części empirycznej.

\section{Założenia i metody badawcze}

B adanie rozpoczęto w lutym 2017 roku, stosując przy tym metodę wywiadu indywidualnego częściowo standaryzowanego niestrukturalizowanego (Kostera, 2003). Wywiady przeprowadzono z 14 kobietami, właścicielkami i/lub założycielkami przedsięwzięć biznesowych w wieku od 22 do 34 lat, których doświadczenie biznesowe obejmowało okres od 8 miesięcy do 4 lat działalności. Dobór próby był celowy. Do badania zaproszono kobiety, które prowadzą co najwyżej małe przedsiębiorstwo i na rynku warszawskim działają nie dłużej nić 5 lat. Niewiele jest opracowań naukowych z zarządzania, w których podejmuje się rozważania wyłącznie na temat kobiet (Bogacz-Wojtanowska, Kostera 2019), choć potrzeba ich reprezentacji w działaniu jest duża (Gabriel, 2009).

Pierwsze wywiady przeprowadzono po spotkaniu „Rozwój i networking dla kobiet” promującym działalność kobiet, kolejne po spotkaniu networkingowym „Professionals and Entrepreneurs", co dalej pozwoliło na zbieranie wywiadów metodą kuli śnieżnej. Rejestrowane wywiady, które trwały od około 75 do 100 minut, poddano znaturalizowanej transkrypcji, co ułatwiło wygenerowanie analitycznych pojęć. Do zakodowania danych wykorzystano program komputerowy ATLAS.ti. Imiona i nazwy własne zostały zastąpione inicjałami. Badanie miało charakter iteracyjny, gdzie poza indukcyjnym podejściem do tworzenia teorii $\mathrm{z}$ danych zastosowano metodę ciągłego porównywania zdarzeń odnoszących się do tych samych kategorii.

\section{Zostając przedsiębiorcą - materiat empiryczny}

Cem niniejszego artykułu jest wskazanie kompeten- cji niezbędnych do efektywnego funkcjonowaniu na rynku w przyszłości, w tym umiejętności, motywacji, postaw i cech $\mathrm{w}$ zakresie przedsiębiorczości.

Przedsiębiorcy działają celowo. Zanim podejmą się określonych działań, określają, co zamierzają osiągnąć albo przynajmniej wytyczają kierunek, w którym będą podążać. Interlokutorzy mieli świadomość, że będą musieli ponieść konkretne nakłady energii własnej, czasu czy koszty. Niekoniecznie jednak byli w stanie oszacować, jaki uzyskają zwrot $\mathrm{z}$ inwestycji. Jednak to nie wstrzymywało ich od podjęcia jakiejkolwiek decyzji. To co ich charakteryzuje, to reagowanie na zastane okoliczności i refleksja nad podjętymi decyzjami. Niejednokrotnie przyznawano, że decyzje byłyby dzisiaj inne, co można uzasadnić zdobytą wiedzą, doświadczeniem, obecnymi priorytetami.

„Jest sporo rzeczy, które mogłam zrobić inaczej, które zaniedbałam, ale myślę, że do pewnych rzeczy trzeba dojrzeć, trzeba trafić na właściwy moment, spotkać właściwych ludzi we właściwym czasie”. (AC)

„Wiem, że zrobiłam dużo takich rzeczy, których inni by nie zrobili. Nie boję się tych zmian, że podejmowałam trudne, dziwne, odważne, raz mądre, raz nie, decyzje". (FG)

Umiejętności podejmowania sprawnie decyzji sprzyja posiadanie cech osobowych jak wytrwałość w działaniu, odwaga czy samodzielność - niezależność $\mathrm{w}$ realizowaniu założeń, co przejawia się $\mathrm{w}$ podejmowaniem działań nieakceptowalnych przez innych $\mathrm{z}$ powodu wysokiego ryzyka.

„Taka samodyscyplina - cały czas praca nad sobą tak, żeby moje życie osobiste nie wpływało na jakość tego, co wykonuję, kontaktu z klientem, jakość produktu". (FG)

„Nauczyłam się nie odmawiać nigdy i naprawdę wiele rzeczy, które teraz mam w swojej jakby historii, portfolio, cv czy w doświadczeniach, jest dlatego, że bałam się, ale mimo wszystko podjęłam takie wyzwanie". (TC)

Konsekwencja $\mathrm{w}$ realizacji celów i odporność psychiczna pozwalają działać przedsiębiorcom w warunkach niepewności i podejmować ryzyko, które niejednokrotnie przekłada się na sukcesy organizacyjne.

„Mam nadzieję, że z biegiem czasu będę bardziej odporna. (...) Nie mam już problemów z [kontaktem z] klientem". (PM)

„Jeśli chcę decydować o najważniejszych sprawach i ta odpowiedzialność musi mieć tę adrenalinę wysoką, i ta odpowiedzialność musi być wysoka”. (WA)

Interlokutorzy podkreślali, że motywowała ich chęć swobody działania i decydowania o sobie i swoim biznesie, pierwsza oferta na ich usługi czy pasja. Podstawą działań jest natomiast zaangażowanie i chęć zrealizowania wyznaczonego celu. Natomiast w przypadku wyzwań fundamentem jest aktywność skoncentrowana na poszukiwaniu 
Tabela 1. Kompetencje w zakresie przedsiębiorczości

\begin{tabular}{|c|c|}
\hline Charakterystyka kompetencji & Wnioski z materiału empirycznego \\
\hline \multicolumn{2}{|c|}{ motywowanie } \\
\hline siebie i innych do realizowania działań (Rakowska, Sitko-Lutek, 2016) & $\begin{array}{l}\text { siebie, narzucanie samodyscypliny; motywowanie i angażowanie do } \\
\text { pracy innych celem odkrycia u nich sily i zasobów }\end{array}$ \\
\hline \multicolumn{2}{|c|}{ niezależność } \\
\hline $\begin{array}{l}\text { autonomia w zakresie realizacji zadania, za które jednostka wzięła } \\
\text { odpowiedzialność (Eurofound, 2018) }\end{array}$ & $\begin{array}{l}\text { finansowa, biznesowa, osobista, decyzyjna - możliwość podejmowania } \\
\text { decyzji niezależnie od opinii osób trzecich }\end{array}$ \\
\hline \multicolumn{2}{|c|}{ odporność } \\
\hline $\begin{array}{l}\text { na funkcjonowanie w warunkach niepewności lub ryzyka; na stres; na } \\
\text { pracę pod presją czasu (Glinkowska, 2017; Wrobel, 2018) }\end{array}$ & $\begin{array}{l}\text { na stres; na niepewność związaną z przyszłością; niepowodzenie; } \\
\text { posiadanie silnej psychiki, która pozwala realizować ambitne cele }\end{array}$ \\
\hline \multicolumn{2}{|c|}{ umiejętność liczenia } \\
\hline $\begin{array}{l}\text { analityczne, w tym zbieranie, filtrowanie, przetwarzanie danych, wnio- } \\
\text { skowanie; tworzenie i ewaluacja informacji (Borowiec-Gabryś i in., 2018; } \\
\text { Eurofound, 2018; Stachowicz-Stanusch, Aleksander, 2018; Wrobel, 2018) }\end{array}$ & brak odwołania \\
\hline \multicolumn{2}{|c|}{ umiejętności konceptualne } \\
\hline $\begin{array}{l}\text { koordynowanie i integrowanie działań; systemowe spojrzenie na problem } \\
\text { i dostrzeganie wpływu zmian na elementy organizacji (Eurofound, 2018; } \\
\text { Glinkowska, 2017) }\end{array}$ & $\begin{array}{l}\text { organizowanie całego przedsięwzięcia - od założenia lub przejęcia } \\
\text { przedsięwzięcia po jego nieustanny rozwój }\end{array}$ \\
\hline \multicolumn{2}{|c|}{ umiejętność pracy zespołowej } \\
\hline
\end{tabular}

angażowanie i motywowanie pracowników w rozproszonych lokalizacjach, współpraca wirtualna, budowanie i współpraca w zespołach wielokulturowych (Eurofound, 2018; Glinkowska, 2017; Rakowska, Sitko-Lutek, 2016)

angażowanie i motywowanie pracowników w jednej lokalizacji

\section{umiejętność komunikowania się}

słuchanie; artykułowanie celów; wyrażanie myśli i poglądów; strukturyzowanie rozmów; negocjowanie; prowadzenie dyskusji i prezentacja argumentów (Glinkowska, 2017; Rachwał, 2019; Stachowicz-Stanusch, Aleksander, 2018; Wrobel, 2018) słuchanie; artykułowanie celów; wyrażanie myśli i poglądów; prowadzenie dyskusji i prezentacja argumentów

\section{kreatywność}

wyobraźnia, myślenie strategiczne, rozwiązywanie problemów, krytyczna i konstruktywna refleksja w ramach ewoluujących procesów twórczych (Dorożyński i in., 2016; Eurofound, 2018; Glinkowska, 2017; Rakowska, Sitko-Lutek, 2016)

rozwiązywanie problemów o charakterze bieżącym, lokalnym zasięgu, dotyczące ludzi, zadań, przedsięwzięcia biznesowego

\section{wytrwałość}

w dążeniu do realizacji zadań w dłuższym okresie czasu (Dorożyński i in., 2016; Glinkowska, 2017; Wrobel, 2018)

optymizm - wytrwałość w dążeniu do celu mimo przeszkód i niepowodzeń; zdolność do poświęceń

\section{zarządzanie}

organizacją, zespołem, procesem, projektem, zasobem; znajomość i rozumienie podejść do planowania i zarządzania/koordynacji (Eurofound, 2018)

przedsięwzięciem, zespołem, projektem; brak wiedzy specjalistycznej - uczenie się na błędach, wymiana doświadczeń z innymi przedsiębiorcami; przyjmowanie rozmaitych ról i kilku specjalizacji w krytycznych sytuacjach (np. fotograf, który wykonuje obowiązki fryzjera, wizażysty, stylisty)

\section{kompetencje etyczne}

odpowiedzialne podejście do stosowania narzędzi, technologii cyfrowych, do własności intelektualnej i kulturowej w kontekście osoby, jej rodziny i społeczności, zagadnień globalnych (Rachwał, 2019) postawa i motywy; działanie zgodnie z prawem i wewnętrznymi przekonaniami; świadomość nieuczciwych praktyk; rozumienie odpowiedzialności za produkt/usługę, otoczenie; szanowanie ludzi; prawdomówność

\section{identyfikacja szans}

zdolność wykorzystywania szans i pomysłów oraz przekształcania ich w wartość, rozwiązywanie problemów (Borowiec-Gabryś i in., 2018; Dorożyński i in., 2016; Eurofound, 2018)

dostrzeganie problemów, które można rozwiązać, identyfikowanie luk rynkowych

podejmowanie inicjatywy

poczucie sprawczości, proaktywność, otwartość na przyszłość (Eurofo- $\quad$ otwartość na ludzi, wyzwania, propozycje und, 2018; Glinka, Gudkova, 2011; Rachwał, 2019)

\section{decyzyjność}

podejmowanie decyzji (Rachwał, 2019)

samodzielne podejmowanie decyzji - od operacyjnych po strategiczne; odwaga; akceptacja zmian; świadome podążanie za marzeniami 
rozwiązań sytuacji problemowej, przykładowo potrzeby zgłaszanej przez odbiorców usług czy produktów finalnych niezrealizowanej dotąd przez rynek. Pozostałe wyzwania dotyczyły zarządzania przedsiębiorstwem, w tym przede wszystkim zarządzania zespołem.

„Planer musiał mi towarzyszyć codziennie. I w końcu przestał on spełniać moje oczekiwania. I to było tak, że sobie wymyśliłam taki planer w końcu, bo już żaden mi się nie podobał". (KO)

"Jeśli widzisz, że jest stagnacja, to możecie wyjść na spacer 30-minutowy i jest to jakieś złamanie schematu. I nowe siły mogą wstąpić w ten zespół”. (TJ)

Przedsiębiorców można podzielić na takich, którzy chcą działać uczciwie zgodnie $\mathrm{z}$ normami społecznie akceptowalnymi, oraz oportunistów zorientowanych wyłącznie na cel, jakim jest maksymalizacja zysków bez względu na rodzaj poniesionych kosztów. W obu przypadkach należałoby założyć uświadomioną celowość zadań, gdzie przedsiębiorca rozumie wagę rezultatów podjętych działań i potencjalnych konsekwencji. Odpowiedzialność za innych i wyniki organizacji, co przejawia się w działaniu zgodnym $\mathrm{z}$ prawem, tj. byciu uczciwym obywatelem, nie tylko stanowi jeden z czynników kształtujących postawę przedsiębiorczą, ale i motyw przedsiębiorczy.

„Pracuję w life coachingu. Ludzie najczęściej nie potrzebują faktury, więc nie ma takiej potrzeby. Natomiast chciałabym się czuć fair w stosunku do państwa i do innych ludzi, którzy też odprowadzają podatki”. (CJ)

„Mam taką wewnętrzną zasadę, że nie polecam tego, czego sama nie spróbowałam, bo uważam, że tylko takie podejście jest fair. (...) Spróbowałam, wiem jak tego używać, wiem co to robi i czym się charakteryzuje, jakie są fakty na ten temat". (FM)

Kolejną ważną kompetencją jest współpraca w zespole, kierowanie nim, wspieranie pracowników w podejmowaniu kolejnych działań, co wymaga umiejętności formułowania komunikatów i argumentów podtrzymujących poziom zaangażowania poszczególnych osób w osiąganiu celów organizacji.

"Jak zatrudniam ludzi czy wysyłam ich na pierwsze kursy, to chciałabym być wsparciem, żeby oni czuli, że jak ja im coś mówię, to nie dlatego, że ja to sobie wymyśliłam w biegu, tylko że faktycznie moje doświadczenie też za tym stoi". (TC)

„Komunikowanie i koordynacja pracy z nimi przy zadaniu. Ja bym powiedziała też, tak naprawdę takie przekazywanie wiedzy i uczenie tych młodszych pracowników”. (GL)

Umiejętność budowania i zarządzania zespołem ludzi, w którym ludzie przedkładają interesy organizacyjne nad osobiste, wymaga umiejętności negocjowania w przypadku interesów sprzecznych i motywowania ich - bezpośrednio lub z wykorzystaniem narzędzi umożliwiających odbiór wiadomości w dowolnym czasie i miejscu.

„Nie można rzucać swojego widzimisię, tylko dawać ludziom wybór i jakby angażować ich w działanie, motywować do takich przemyśleń, pomagając im w pracy i zdecydować a propos ważnej rzeczy - natomiast nie można narzucać swojego zdania”. (MO)
„Trzeba przyjść w miarę wcześniej, żeby nie demotywować zespołu, że ktoś śpi sobie dłużej albo załatwia coś swojego. Po drugie trzeba wykonać pracę i wreszcie być dostępnym dla klientów”. (PM)

W tabeli 1 zestawiono charakterystyki nadmienione w przeglądzie literatury nawiązujące do każdej z kompetencji w zakresie przedsiębiorczości ujętej w Zaleceniu Rady z 2018 roku na temat kompetencji kluczowych. Te charakterystyki zestawiono $\mathrm{z}$ wnioskami $\mathrm{z}$ analizy materiału empirycznego.

Nie zidentyfikowano odniesienia w materiale empirycznym do wielokulturowości i zdolności obliczeniowych, co może wynikać z profilu działalności osób badanych, które zajmują się przykładowo projektowaniem biżuterii, produkcją wyrobów piśmienniczych czy nauczaniem. Z kolei poczucie własnej skuteczności, umiejętności konceptualne i zarządzanie nie zostały nazwane wprost, choć występują. Kobiety pracują na rynku lokalnym, a swoje przedsięwzięcia dopiero rozwijają - nie zbudowały jeszcze hierarchii organizacyjnej, nie dookreśliły struktury organizacyjnej, pracowników nie traktują jako podwładnych - częściej określają ich jako współpracownik, uczennica, partner. Analiza ujawniła dodatkowo, że kobiety-przedsiębiorcy charakteryzują się cechami osobowymi, takimi jak: energiczność, pracowitość, siła odpowiadająca zaangażowaniu czy odwaga. Są świadome celowości realizowanych zadań i odpowiedzialności za powzięte decyzje. Podkreślają przy tym, że w prowadzeniu inicjatywy przedsiębiorczej pozostają same. Wiedzę specjalistyczną poszerzają $\mathrm{w}$ procesie dokształcania się, ale i podejmowania prób czy wymiany wiedzy z innymi przedsiębiorcami, przy czym wiedza nabyta w ten sposób stanowi jedynie wskazówki do podejmowania kolejnych kroków.

\section{Podsumowanie}

$\mathbf{R}$ ola przedsiębiorców na przełomie dekad wzmocniła się, a ich wkład jest zauważalny przez szersze grono uczestników rynku. Ugruntowała się także pozycja przedsiębiorczości, którą formalnie uznano za kompetencję kluczową i postrzega się jako ważną w przyszłości w życiu gospodarczym i społecznym, co jest podyktowane kierunkiem zmian cywilizacyjnych. Energia twórcza, chęć działania i pomysłowość nadal stanowią podwaliny przedsiębiorczości. Mając świadomość wagi kompetencji kluczowych w ogóle, można efektywniej kształcić w kierunku potrzeb zgłaszanych przez środowisko biznesowe. Odpowiednia ich kombinacja może sprzyjać wzrostowi dobrobytu, samorealizacji, właściwemu reagowaniu w sytuacjach kryzysowych czy włączeniu społecznemu. Kompetencje w zakresie przedsiębiorczości są o tyle istotne, że wpływają na działania osób podejmujących inicjatywy przedsiębiorcze stanowiące główny czynnik rozwoju gospodarczego.

Należy podkreślić, że zinterpretowane dane nie pozwalają na generalizację i uogólnianie wyników badania na całą populację młodych przedsiębiorców. Mimo to badania jakościowe pozwalają na analizę pojedynczych incydentów, które zachodzą w gospodarce. Ciekawe do eksploracji wydaje się szczegółowe zbadanie poszczególnych kategorii 
przedsiębiorców, przykładowo według branży, okresu działania, tworzonych wartości dla klienta. Do potencjalnych obszarów badawczych należy również porównanie roli społecznej kobiet i mężczyzn-przedsiębiorców czy analiza skuteczności strategii rozwoju mikroprzedsiębiorstw.

\section{dr Julita Majczyk \\ Uniwersytet Warszawski \\ Wydział Zarządzania \\ ORCID: 0000-0003-4166-4981 \\ e-mail: jmajczyk@wz.uw.edu.pl}

\section{Bibliografia}

[1] Bandura A. (1997), Self-Efficacy, „Harvard Mental Health Letter", Vol. 13, No. 9, pp. 4-6.

[2] Bauman Z. (1996), Etyka ponowoczesna, Aletheia, Warszawa.

[3] Bogacz-Wojtanowska E., Kostera M. (2019), Siłaczki, szefowe, społeczniczki: Polki, organizatorki, Wydawnictwo Uniwersytetu Jagiellońskiego, Kraków.

[4] Borowiec-Gabryś M., Kilar W., Rachwał T. (2018), Przedsiębiorczość jako kompetencja przyszłości, [w:] S. Kwiatkowski (red.), Kompetencje przyszłości, Fundacja Rozwoju Systemu Edukacji, Warszawa, s. 68-89.

[5] Dorożyński T., Świerkocki J., Urbaniak W. (2016), Employers Expectations vis-à-vis Graduates of Faculties of Economics. Results of a Direct Study, „Comparative Economic Research”, Vol. 19, No. 2, pp. 93-109.

[6] Eurofound (2018), Wage and Task Profiles of Employment in Europe in 2030, Publications Office of the European Union, Luxembourg.

[7] Gabriel Y. (2009), Reconciling an Ethic of Care with Critical Management Pedagogy, „Management Learning”, Vol. 40, No. 4, pp. 379-385.

[8] Glinka B., Gudkova S. (2011), Przedsiębiorczość, Wolters Kluwer, Warszawa.

[9] Glinkowska B.A. (2017), Characteristics and Competences of a Contemporary Polish Manager Working in International Markets, „Journal of Positive Management, Vol. 8, No. 2, pp. 57-68.

[10] Goliński M., Graczyk-Kucharska M., Spychała M., Szafrański M. (2017), Doskonalenie kodu kompetencji zawodowych w przedsiębiorstwach - case study, „Przegląd Organizacji”, Nr 3, s. 54-59.

[11] Hauswald E. (1919), Produktywizm. Nowoczesny system gospodarczo-społeczny, Drukiem Wł. Poturalskiego, Kraków.

[12] Instytut Analiz Rynku Pracy (2019), Rynek pracy, edukacja, kompetencje. Aktualne trendy i wyniki badań, Polska Agencja Rozwoju Przedsiębiorczości, Warszawa.

[13] Kostera M. (2003), Antropologia organizacji: Metodologia badań terenowych, Wyd. Naukowe PWN, Warszawa.

[14] Kupczyk T., Stor M. (2017), Zarzadzanie kompetencjami: teoria, badania i praktyka biznesowa, Wyższa Szkoła Handlowa we Wrocławiu, Wrocław.

[15] Kwiatkowski S. (red.), (2018), Kompetencje przyszłości, Seria Naukowa, t. 3, Fundacja Rozwoju Systemu Edukacji, Warszawa.

[16] Majczyk J. (2019), Stworzyć lidera. Od wizerunku beniaminka do rozgrywajacego $w$ biznesie, Wydawnictwo Naukowe Wydziału Zarządzania Uniwersytetu Warszawskiego, Warszawa.
[17] Murtazova Z.A., Murtazova L.Z. (2018), Development of Entrepreneurial Competence of Students through Training in Business English and Information Technologies, „ESPACIOS”, Vol. 39, No. 20, pp. 3.

[18] Ng H., Kee D. (2018), The Core Competence of Successful Owner-managed SMEs, „Management Decision”, Vol. 56, No. 1, pp. 252-272.

[19] PARP (2018), Raport o stanie sektora matych $i$ średnich przedsiębiorstw w Polsce, Polska Agencja Rozwoju Przedsiębiorczości, Warszawa.

[20] Rachwał T. (red.), (2019), Ksztaltowanie kompetencji przedsiębiorczych, Seria Naukowa, t. 5, Fundacja Rozwoju Systemu Edukacji, Warszawa.

[21] Rakowska A., Sitko-Lutek A. (2016), Kluczowe Kompetencje Pracowników Przyszłości w Opinii Ekspertów Międzynarodowych - Wyniki Badań, Prace Naukowe Uniwersytetu Ekonomicznego we Wrocławiu, $\mathrm{Nr} 429$, s. 173-185.

[22] Richert-Kaźmierska A. (2010), Władze samorzadowe w procesie kreowania przedsiębiorczości, „Studia i Materiały. Miscellanea Oeconomicae", Nr 14, s. 269-278.

[23] Sobczyk G. (2016), Rola i źródła informacji rynkowych $w$ dziatalności przedsiębiorstw - wyniki badania, „Annales Universitatis Mariae Curie-Skłodowska, Sectio H Oeconomia”, Nr 50, z. 3, s. 173-184.

[24] Stachowicz-Stanusch A., Aleksander A. (2018), Kompetencje Przyszłości, Zeszyty Naukowe Politechniki Śląskiej, seria Organizacja i Zarządzanie, Nr 121, s. 485-497.

[25] Szukalski S.M. (2017), Rynek pracy wobec globalizacji, transgraniczności procesów biznesowych i kryzysu ekonomicznego, „Studia Prawno-Ekonomiczne", Nr 102, s. 259-272.

[26] Tehseen S., Ahmed F., Qureshi Z., Uddin J.M., Ramayah T. (2019), Entrepreneurial Competencies and SMEs' Growth: The Mediating Role of Network Competence, „Asia-Pacific Journal of Business Administration", Vol. 11, No. 1, pp. 2-29.

[27] Wach K. (2014), Paradygmat gospodarki przedsiębiorczej a polityka wspierania przedsiębiorczości, [w:] K. Zieliński (red.), Formy i przejawy wspótczesnej przedsiębiorczości w Polsce, Difin, Warszawa, s. 13-30.

[28] Wrobel M. (2018), Do You Have What It Takes to Become an Internet Entrepreneur? The Key Competencies of Successful Founders, [in:] N. Richter, P. Jackson, T. Schildhauer (eds.), Entrepreneurial Innovation and Leadership, Palgrave Pivot, Cham, pp. 51-63.

[29] Zalecenie Rady z dnia 22 maja 2018 r. w sprawie kompetencji kluczowych w procesie uczenia się przez całe życie (Tekst mający znaczenie dla EOG), Dz. UE 2018/C 189/01.

\section{On Entrepreneurship as a Key Competence of the Future}

\section{Summary}

The purpose of this study is to show the role of competences of an entrepreneur who contributes actively to economic development. The entrepreneurial process and activities are perceived as the foundation of economic development, a tool for reducing unemployment, while entrepreneurs are seen as decision-makers in the economic environment. Thus, the theoretical part presents research on future key 
competences determining economic activity. In order to identify the competence in the field of entrepreneurship among Polish entrepreneurs, an analysis was carried out that comprised their opinions on undertaken actions and the type of performed tasks, which lead to the business entity creation and further to its development. The study concludes with a discussion on the expectations of the institutions towards people participating in economic development and the how the practitioners perceive the issue of competence.

\section{Keywords}

collaboration, initiative, perseverance, creativity 